\title{
Characterisation of the interaction of Pseudomonas putida and Pseudomonas tolaasii with Trichoderma aggressivum
}

\author{
Dejana Kosanovic • Gerard Sheehan • Helen Grogan • \\ Kevin Kavanagh
}

Accepted: 27 September 2019/Published online: 25 October 2019

(C) Koninklijke Nederlandse Planteziektenkundige Vereniging 2019

\begin{abstract}
Green mould disease is caused by Trichoderma aggressivum which colonizes mushroom compost and reduces yield. Two Pseudomonas species are associated with mushroom compost: Pseudomonas putida, which stimulates mushroom pinning, and Pseudomonas tolaasii which has a negative effect on crop production. The aim of this work was to characterize T. aggressivum - Pseudomonas interactions as these may be important factors in the development of green mould disease. $P$. tolaasii supernatant inhibited growth by $57 \%$ but $P$. putida stimulated growth of $T$. aggressivum by $44 \%$. Tolaasin production was identified in P. tolaasii cultures with a peak at $96 \mathrm{~h}$. Fluorescent microscopy examination of $T$. aggressivum hyphae revealed that exposure to $P$. tolaasii supernatant decreased mycelial formation while increasing the abundance of conidia. Label free proteomic analysis of changes in the abundance of $T$. aggressivum proteins indicated that exposure to $P$. tolaasii supernatant lead to an oxidative stress response and catabolic enzyme
\end{abstract}

Electronic supplementary material The online version of this article (https://doi.org/10.1007/s10658-019-01867-z) contains supplementary material, which is available to authorized users.

D. Kosanovic · G. Sheehan · K. Kavanagh $(\bowtie)$

Department of Biology, Maynooth University, Maynooth, Co.

Kildare, Ireland

e-mail: Kevin.Kavanagh@mu.ie

H. Grogan

Teagasc, Horticulture Development Department, Ashtown

Research Centre, Dublin 15, Ireland activation (mitochondrial import inner membrane translocase complex (5.7-fold), oxidoreductase (5.2fold), glucoamylase $(5.1$-fold)). Exposure of T. aggressivum to $P$. putida supernatant lead to an increase in the abundance of proteins associated with growth and development (structural constituents of ribosome (20-fold), H/ACA ribonucleoprotein complex subunit (18-fold), DNA binding and nucleosome assembly protein (5.3-fold), and prefoldin (5-fold)). These results indicate that exposure to $P$. putida can stimulate the growth of $T$. aggressivum and this interaction may be an important factor in increasing green mould disease in mushroom crops and so reducing yield.

Keywords Agaricus · Trichoderma Proteomics · Pseudomonas
Abbreviations
FDR False Discovery Rates
GO gene ontology
SSDA statistically significant differentially abundant
DEP differentially expressed proteins (DEP)
NB Nutrient broth
SN supernatant

\section{Introduction}

White button mushroom (Agaricus bisporus (Lange) Imbach) accounts for $15 \%$ of total mushroom production worldwide, with a production of 4.43 billion $\mathrm{kg}$ in 
2013 and it is the most commonly cultivated mushroom in North America and Europe (Royse et al. 2017). In mushroom cultivation, naturally occurring bacteria and fungi coexist in the compost, breaking down nutrient rich straw and manure and preparing the substrate for A. bisporus growth (Chang and Miles 2004; Potocnik et al. 2012). Minor green mould diseases are caused by several species of the genus Trichoderma which have been present in mushroom industry for many years (Sinden and Hauser 1953; Fletcher and Gaze 2008). In the early 1980s a new species was identified in Ireland as T. aggressivum (Seaby 1987, 1996) and there have been many reports of its spread worldwide (Rinker 1993; Romaine et al. 1996; Geels 1997; Hermosa et al. 1999; Mamoun et al. 2000; Hatvani et al. 2007; Szczech et al. 2008; Romero-Arenas et al. 2009; Clift and Shamshad 2009; Hatvani et al. 2012; Kosanovic et al. 2013). This filamentous micro-fungus is a rapidly growing, aggressive competitor that has evolved and adapted to a specific mushroom growing niche (Kredics et al. 2010; Kosanovic et al. 2015). It colonizes the substrate and casing for A. bisporus growth, influences the mushroom yield and causes severe crop losses (O'Brien et al. 2017). It has been shown that the dilution level of T. aggressivum inoculum in A. bisporus compost directly correlates with reduction in mushroom yield. Crop loss of 2 to $6 \%$ has been found at the dilution level of $10^{-4}$ and 60 to $100 \%$ loss at the $10^{-1}$ level (O'Brien et al. 2017). Our unpublished data show that a $10^{-4}$ T. aggressivum inoculation $\left(4.5 \times 10^{8}\right.$ conidia/g) leads to 20 to $50 \%$ crop loss and a $10^{-3}$ inoculum $\left(4.5 \times 10^{9}\right.$ conidia/g) results in A. bisporus yield loss of 60 to $85 \%$, indicating variability in crop responses. Strains of naturally occurring compost and casing organisms, Arthrobacter terregens, Bacillus megaterium and Rhizobium sp., have been found to stimulate fruiting of A. bisporus (Park and Agnihotri 1969). Pseudomonas bacteria, such as Pseudomonas putida, are significant promoters of mushroom fruiting body formation (Rainey 1991) since 10\% of compost and sometimes more than $50 \%$ of casing bacteria belong to Pseudomonas genus (Godfrey et al. 2001). The exact mechanism that stimulates mushroom pinning has not been established, but it has been suggested that bacteria promote pinning by consumption of self-inhibitor compounds known as 1-octen-3-ol and 2-ethyl-1-hexanol produced by A. bisporus mycelium (Noble et al. 2009; Zarenejad et al. 2012). Other compost and casing Pseudomonas spp. are mycopathogens and these can cause diseases in mushrooms such as brown $(P$. tolaasii) and ginger ( $P$. gingeri) blotch of Agaricus bisporus (Tolaas 1915; Wong et al. 1982) and drippy gill disease or yellow (P. agarici) blotch of white button mushrooms (Young 1970; Soler-Rivas et al. 2000). P. reactans can cause brown discoloration on mushrooms (Wells et al. 1996) but Pseudomonas tolaasii which can produce tolaasin is the causative agent of mushroom brown blotch disease (Cho et al. 2007; Mohammad and Sabaa 2015) which is found worldwide (Saxon et al. 2014) and causes rapid decline in the quality of the mushroom crop (Soler-Rivas et al. 1999). Even though mushrooms with brown blotch disease do not cause health problems in humans, they cause economic losses due to reduced quality and consumers prefer to select entirely white mushrooms without brown spots on the mushroom caps (Soler-Rivas et al. 1999). The aim of this study was to characterize the interaction of $P$. putida and $P$. tolaasii with $T$. aggressivum, and to establish if they could increase the incidence and severity of green mould disease. Both Pseudomonas species are endemic for Agaricus bisporus compost beds, but one is considered beneficial and the other is a potential threat to yield excellence. Also, P. tolaasii can change from virulent to avirulent form (Saxon et al. 2014). Recent advances in proteomic technologies can produce new insights into microbial interactions. These technologies include large scale mass spectrometry-based proteomics capable of identifying and quantifying thousands of proteins across multiple samples in a single run (Zhang et al. 2013; Yates et al. 2009; Watson et al. 2015; Zhu et al. 2013; Barribeau et al. 2014). Label free quantitative (LFQ) mass spectrometry (MS) was used to compare proteomes of T. aggressivum treated with P. putida or $P$. tolaasii supernatant to gain a deeper understanding of any interactions by characterizing differences in the relative abundance of proteins. The mycopathogen T. aggressivum and the bacteria $P$. putida and $P$. tolaasii are present in the compost at the same time and fungal - bacterial interactions may be important factors in disease development in the crop.

\section{Materials and methods}

Culture conditions

T. aggressivum 100526 (acquired from the Royal Netherlands Academy of Arts and Science, 
Ultrecht, Netherlands), and P. putida and P. tolaasii isolated from mushroom compost (Teagasc, Ireland) and preserved in liquid nitrogen culture collection of Maynooth University were used in this study. Trichoderma cultures were grown in malt extract broth (MEB) (Oxoid) at $30{ }^{\circ} \mathrm{C}$ and $200 \mathrm{rpm}$ for up to 2 days. Stocks were maintained on malt extract agar (MEA) (Oxoid). Pseudomonas cultures were grown in nutrient broth (NB) (Oxoid) at $30{ }^{\circ} \mathrm{C}$ for up to 5 days, and after $24 \mathrm{~h}, 48 \mathrm{~h}, 72 \mathrm{~h}, 96 \mathrm{~h}$ and $120 \mathrm{~h}$ centrifuged and filter-sterilized through $20 \mu \mathrm{m}$ syringe filters to produce supernatants. Bacterial stocks were maintained on nutrient agar (NA) (Oxoid).

\section{Virulence test}

Virulence assay was performed by the inoculation of the harvested pilei of $A$. bisporus with bacteria suspension $\left(1 \times 10^{13} \mathrm{CFU} \mathrm{ml}^{-1}\right)$ prepared from an overnight culture of Pseudomonas tolaasii in nutrient broth. Stipes were removed from all basidiomes and top of the pilei were inoculated with $20 \mu \mathrm{l}$ of bacteria suspension. Three replicates per each isolate were applied. Sterile water was used as a negative control. Inoculated pilei were kept at room temperature $\left(22 \pm 2{ }^{\circ} \mathrm{C}\right)$. Symptoms were rated as follows: $0=$ no symptoms; $1=$ brown blotch around inoculation site.

\section{Zone of inhibition assay}

Filter-sterilized P. putida and P. tolaasii supernatants were transferred onto $10^{4}$ T. aggressivum conidia inoculated potato dextrose (PDA) and malt extract (ME) agar plates. Plates were incubated at $30{ }^{\circ} \mathrm{C}$ for $48 \mathrm{~h}$ and examined for zones of inhibition around the wells containing $50 \mu \mathrm{l}$ of $96 \mathrm{~h}$ bacterial supernatant.

Assessment of effect of bacterial supernatants on growth of T. aggressivum

Cultures $(50 \mathrm{ml})$ of $T$. aggressivum $10^{4}$ conidia $/ \mathrm{ml}$ grown for $48 \mathrm{~h}$ at $30{ }^{\circ} \mathrm{C}$ and $200 \mathrm{rpm}$ with $25 \% \mathrm{v} / \mathrm{v}$ supernatants were harvested by centrifugation at $4143 \times \mathrm{g}$ for $15 \mathrm{~min}$. The supernatant was discarded, and wet mass was measured.
Organic extraction of bacterial supernatants for HPLC analysis

Filter-sterilized P. putida and P. tolaasii supernatants were organically extracted by mixing in a $1: 1$ ratio with chloroform and shaken for $2 \mathrm{~h}$. The organic phase was collected and evaporated on Rotavapor-R (Buchi, Switzerland) and re-suspended in methanol. Organic extracts were analyzed on a Shimadzu (SPD-M20A, Japan) with C-18 HPLC column using diode array detection with multiple wavelengths $(220,254,280 \mathrm{~nm})$. Flow rate was $1 \mathrm{ml} / \mathrm{min}$ with an injection of $20 \mu \mathrm{l}$ per sample. Tolaasin standard was a kind gift from Dr. Yeong-Bae Yun (Cho et al. 2007) and was used to verify and quantify tolaasin in supernatants.

\section{Fluorescent microscopy}

T. aggressivum culture was grown for $24 \mathrm{~h}$ at $30^{\circ} \mathrm{C}$ and $200 \mathrm{rpm}$ and then supplemented with $P$. putida or P. tolaasii supernatants to final concentration of $25 \%$ $\mathrm{v} / \mathrm{v}$ and incubated for additional $24 \mathrm{~h}$ under the same conditions. Hyphae were isolated, transferred to a glass slide, washed with PBS three times and stained with Calcofluor white (Sigma-Aldrich) for $5 \mathrm{~min}$ at room temperature. The samples were washed twice (PBS) and a cover slide was placed on top. Mycelium was viewed using an Olympus BX61 fluorescent microscope.

Label free quantitative proteomics of T. aggressivum treated with $P$. putida/tolaasii supernatants

Protein was extracted (Maher et al. 2018) from T. aggressivum mycelium which was grown for $24 \mathrm{~h}$ and then supplemented with $P$. putida or $P$. tolaasii supernatants $(n=3)$ for an additional $24 \mathrm{~h}$. Bradford method was applied to quantify protein for acetone precipitation overnight. Samples were centrifuged at $14500 \times \mathrm{g}$ for $10 \mathrm{~min}$, and the pellet was re-suspended in $25 \mu \mathrm{l}$ of $6 \mathrm{M}$ urea, $2 \mathrm{M}$ thiourea and $0.1 \mathrm{M}$ Tris- $\mathrm{HCl} 150$ buffer $(\mathrm{pH} 8.0)$. Protein was reduced with dithiothreitol (0.5 M DTT), alkylated with iodoacetamide (0.55 M IAA) and digested with sequence grade trypsin (Promega, Ireland) at a trypsin: protein ratio of $1: 40$, overnight at $37^{\circ} \mathrm{C}$. Tryptic peptides were purified for mass spectrometry using C18 spin columns (Medical Supply Company, Ireland) and $0.75 \mu \mathrm{g}$ of peptide mix was eluted onto a 
QExactive (ThermoFisher Scientific, USA) high resolution accurate mass spectrometer connected to a Dionex Ultimate 3000 (RSLCnano) chromatography system. Peptides were separated by an increasing acetonitrile gradient from $2 \%-40 \%$ on a Biobasic C18 Picofrit column (100 mm length, $75 \mathrm{~mm}$ ID), using a 120-min reverse phase gradient at a low rate of $250 \mathrm{nl} / \mathrm{min}$. A full MS scan of range 200-2000 was followed to select the 15 most intense ions prior to MS/MS. Protein identification from this data was performed using the Andromeda search engine in Max-Quant (version 1.2.2.5) to correlate against a Trichoderma spp. (proteome of T. harzianum was analysed since it is phylogenetically closest to T. aggressivum (Kosanovic et al. 2013) database downloaded from www.uniprot.org.

The MS proteomic data and MaxQuant search output files have been added to the ProteomeXchange Consortium (Côté et al. 2012) via the PRIDE partner repository with the dataset identifier PXD012656. The Perseus software package (v. 1.5.5.3) was used for results processing, statistical analyses and graphics generation. LFQ intensities were $\log _{2}$-transformed and ANOVA of significance and t-tests between the treated groups was performed using a $p$ value of 0.05 and significance was determined using FDR correction (Benjamini and Hochberg 1995). Proteins which had non-existent values (suggestive of absence or very low abundance in a sample) were also used in statistical analysis. Proteins found to be absent (below the level of detection) in one or more treatments and present (above the level of detection) in three or fewer treatments were also used in statistical analysis of the total differentially expressed group following imputation of the zero values with values that simulate low abundant proteins.

The Search Tool for the Retrieval of INteracting Genes/Proteins (STRING) v10.5 (http://string-db.org/) was used to map known and predicted protein:protein interactions. UniProt gene lists (extracted from Perseus) were inputted and analyzed in STRING using the medium confidence $(0.5)$ setting to produce interactive protein networks for proteins increased and decreased in abundance.

These proteins were subjected to Gene Ontology (GO) analysis by Blast2GO software tool (https://www.blast2 go.com/). Statistically enriched GO descriptors were examined to identify clusters of proteins enriched within statistically significant differentially abundant (SSDA) protein lists $(p<0.05)$.
Statistical analysis

All experiments were carried out on three independent occasions, and results were expressed as the mean $\pm \mathrm{SE}$. Significant differences were considered at $p<0.05$.

\section{Results}

Virulence test

In vitro pathogenicity testing was performed to assess the virulence of the $P$. tolaasii isolate used in the experimental work since $P$. tolaasii may undergo a change from virulent (pathogenic, non-fluorescent, smooth colony morphology on King's Medium B Agar) to avirulent (non-pathogenic fluorescent rough colony morphology) forms (Saxon et al. 2014). According to the results, $P$. tolaasii used in this work was a virulent form and caused brown spots on mushroom caps (Figure S1).

\section{Assessment of effect of $P$. tolaasii and P. putida supernatants on T. aggressivum growth}

The effect of $P$. tolaasii and P. putida supernatants on T. aggressivum growth was assessed after $48 \mathrm{~h}$. P. tolaasii supernatant was found to significantly ( $p=$ 0.05 ) inhibit growth, while $P$. putida supernatant significantly $(p=0.01)$ stimulated growth of $T$. aggressivum (Fig. 1). It was found that in samples containing $25 \% \mathrm{v} / \mathrm{v}$ $P$. putida supernatant mycelial growth was increased by $44 \%$, whereas $25 \% \mathrm{v} / \mathrm{v}$ P. tolaasii supernatant inhibited the growth of T. aggressivum by $57 \%$. P. tolaasii $96 \mathrm{~h}$ supernatant induced zones of inhibition on PDA and ME agar plates inoculated with $10^{4}$ T. aggressivum conidia for $48 \mathrm{~h}$ at $30{ }^{\circ} \mathrm{C}$ (Figure S2a, b). In contrast $P$. putida $96 \mathrm{~h}$ supernatant produced no zone of inhibition on PDA or ME agar plates (Figure S2c, d).

Detection and quantification of tolaasin in P. tolaasii supernatant

P. tolaasii and P. putida were cultured at $30^{\circ} \mathrm{C}$ to produce supernatants at different time points. Supernatants were organically extracted as described and quantified by HPLC to the presence of tolaasin in $P$. tolaassii cultures. The retention time for tolaasin was found to be $17.41 \mathrm{~min}$ (Figure S3). Tolaasin was detected only in P. tolaasii 96- 
Fig. 1 T. aggressivum growth [g] in MEB after $48 \mathrm{~h}$ incubation at $30{ }^{\circ} \mathrm{C}$, containing $25 \% \mathrm{v} / \mathrm{v}$ of either: Nutrient Broth, P. putida 96 h supernatant or $P$. tolaasii 96 h supernatant. $* p=0.05, * *$ $p=0.01, * * * p=0.001$

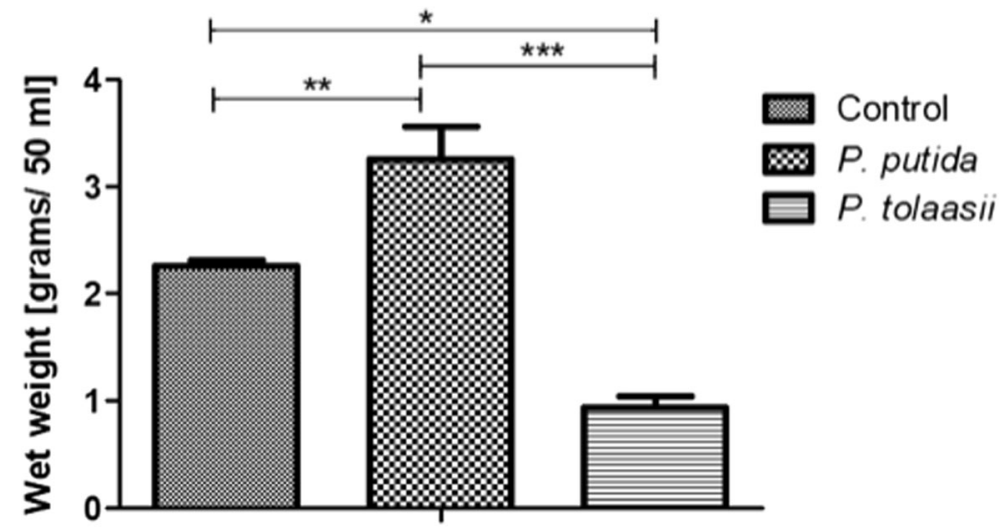

T. aggressivum and 120-h supernatants, with the highest concentration being present at $96 \mathrm{~h}$. The tolaasin concentration at $120 \mathrm{~h}$ was $29.88 \mu \mathrm{g}$ in $50 \mathrm{ml}$ P. tolaasii supernatant, whereas a total of $154.08 \mu \mathrm{g}$ of tolaasin was present in $50 \mathrm{ml}$ of P. tolaasii supernatant at $96-\mathrm{h}$ culture.

Fluorescent microscopic examination of Trichoderma hyphae

Fluorescent microscopy examination of $T$. aggressivum hyphae stained with calcofluor revealed that exposure to P. tolaasii supernatant (Fig. 2g, h, i) decreased mycelial formation while increasing the abundance of conidia compared to P. putida supernatant exposure (Fig. 2d, e, f) and control groups (Fig. 2a, b, c). Elongated, branched T. aggressivum hyphae with septa dividing cells were observed in P. putida supernatant treated and control groups. In contrast fewer hyphae were observed in P. tolaasii treated group and these were short and rounded, with few septa dividing cells due to disruption of mycelial growth. Additionally, P. tolaasii treated T. aggressivum samples displayed abundant spore formation, compared to other two groups (Fig. 2g, h, i).

Proteomic analysis of response of Trichoderma after exposure to $P$. putida and $P$. tolaasii

In total 21,881 peptides were identified, representing 2820 proteins. Results of label free proteomic investigation of T. aggressivum proteins after exposure to P. tolaasii or P. putida supernatant indicated that exposure to $P$. putida supernatant lead to a $30 \%$ increase in different proteins compared to the ones exposed to $P$. tolaasii supernatant and the control group.
According to Perseus analysis a total of 161 T. aggressivum proteins in $P$. tolaasii treatment and 167 proteins in P. putida treatment were determined to be differentially abundant (analysis of variance [ANOVA], $P<0.05$ ), with a fold change value of $>2$. A total of 768 (P. putida) and 286 (P. tolaasii) T. aggressivum proteins were deemed exclusive (i.e., with LFQ intensities present in all three replicates of one treatment and absent in all three replicates of the other two treatments). These proteins were also used in statistical analysis of the total levels corresponding to the differentially expressed group members following imputation of the zero values as described above. After data imputation, these proteins were included in the subsequent statistical analysis.

A principal-component analysis (PCA) performed on all filtered proteins distinguished the control and P. putida/tolaasii -treated samples, indicating a clear difference between the proteomes (Figure S4). Proteins that increased in relative abundance in P. putida -treated T. aggressivum compared to the control were structural constituents of ribosome (20-fold), H/ACA ribonucleoprotein complex subunit (18-fold), cyanide-degrading nitrilase (11-fold), signal recognition particle $54 \mathrm{kDa}$ protein (6.4-fold), DNA binding and nucleosome assembly protein (5.3-fold), prefoldin subunit 3 (5-fold), and integral component of membrane (4.8-fold) (Fig. 3a). Proteins decreased in relative abundance in P. putida -treated T. aggressivum were Omethyltransferase activity protein (17.5-fold), mitochondrial 2-methylisocitrate lyase (14.6-fold), GMC oxidoreductase (13.5-fold), nitrate assimilation protein (12.4-fold), and nucleoside catabolic process unit (4.8fold) (Fig. 3a). 


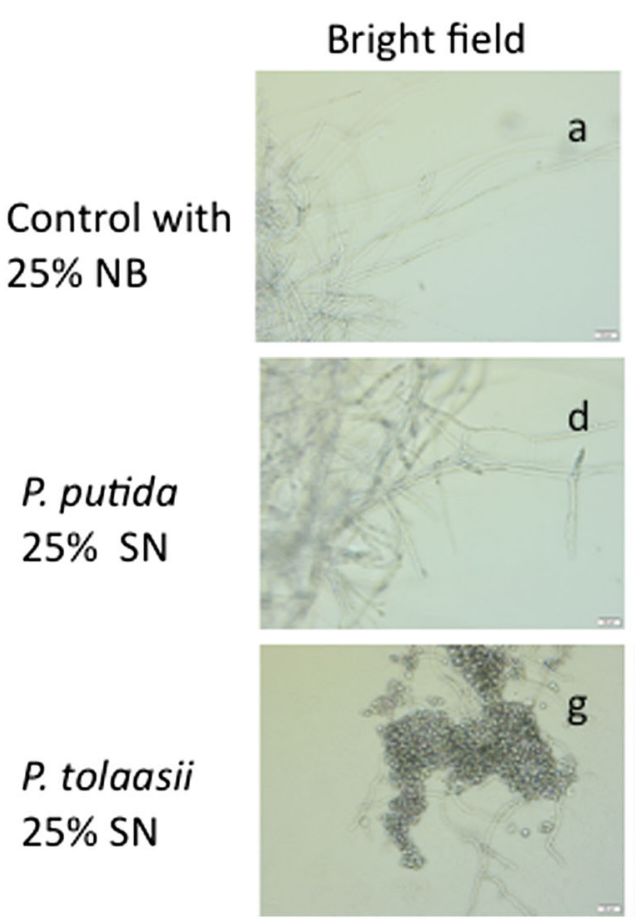

Fig. 2 Fluorescent microscopy 20x magnification, $48 \mathrm{~h}$ at $30^{\circ} \mathrm{C}$. Photomicrograph of calcofluor stained hyphae showing that P. tolaasii $(\mathrm{g}, \mathrm{h}, \mathrm{i}) 96 \mathrm{~h}$ supernatant $(\mathrm{SN})$ added in $25 \%$ to

Proteins that increased in relative abundance in P. tolaasii -treated T. aggressivum compared to the control were mitochondrial import inner membrane translocase complex protein (5.7-fold), pseudouridine synthesis (5.5-fold), protein folding (5.4-fold), prefoldin complex (5.4-fold), oxidoreductase (5.2-fold), mitochondrial respiratory chain complex III assembly (5.2-fold), and glucoamylase (5.1fold) (Fig. 3b). Proteins decreased in relative abundance in $P$. tolaasii -treated T. aggressivum were $\mathrm{O}$ methyltransferase activity protein ( 8 -fold), carboxylic acid metabolic process protein $(6.8$-fold), isocitrate lyase activity (6.8-fold), fatty-acyl-CoA binding protein (6-fold), serine-type endopeptidase activity (5.2-fold), hydrolases (4.6-fold), tricarboxylic acid cycle protein (4.4-fold), malate synthase (4.3-fold), and nucleoside diphosphate kinase (4fold) (Fig. 3b).

According to STRING analysis (string-db.org) there was no significant enrichment of protein groups seen in $T$. aggressivum sample treated with $P$. tolaasii. However, proteins were found to have more interactions among themselves than expected, indicating that they are biologically connected as a

\section{Merge}
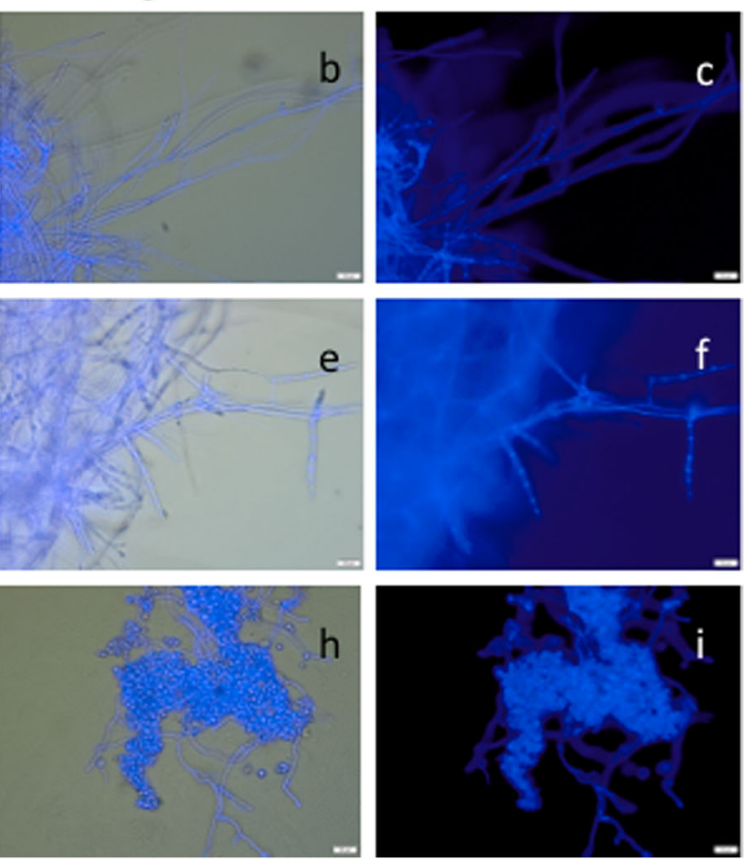

T. aggressivum growing culture decreases mycelial formation while increasing the conidia abundance compared to the same percent supernatant of $P$. putida $(\mathrm{d}, \mathrm{e}, \mathrm{f})$ and control $(\mathrm{a}, \mathrm{b}, \mathrm{c})$ groups

group. For the samples treated with P. putida supernatant functional enrichments were found in prefoldin (prefoldin, prefoldin beta-like) and aldo/keto reductase family (aldo/keto reductase/potassium channel subunit beta and NADP dependant oxidoreductase domain). Prefoldin promotes protein folding in cells and aldo/keto reductase family reduces organic compounds.

Proteins were subjected to Gene Ontology (GO) analysis by Blast2GO software tool. A number of GO terms belonging to biological process (small molecule metabolic process, response to stress, cellular component organization and biosynthetic process), molecular function (ion binding, oxidoreductase activity, structural constituent of ribosome and organic cyclic compound binding), cellular component (intracellular organelle, membrane-bounded organelle, intracellular and endomembrane system) were significantly enriched within the dataset, with ion binding, hydrolase and oxidoreductase activity enriched with $P$. tolaasii group (Figure S5). Hydrolases, oxidoreductases and transferases were the most enriched enzymes categories amongst proteins identified in T. aggressivum treated groups, with hydrolases being the most abundant in P. tolaasii treated group (Fig. 4). 

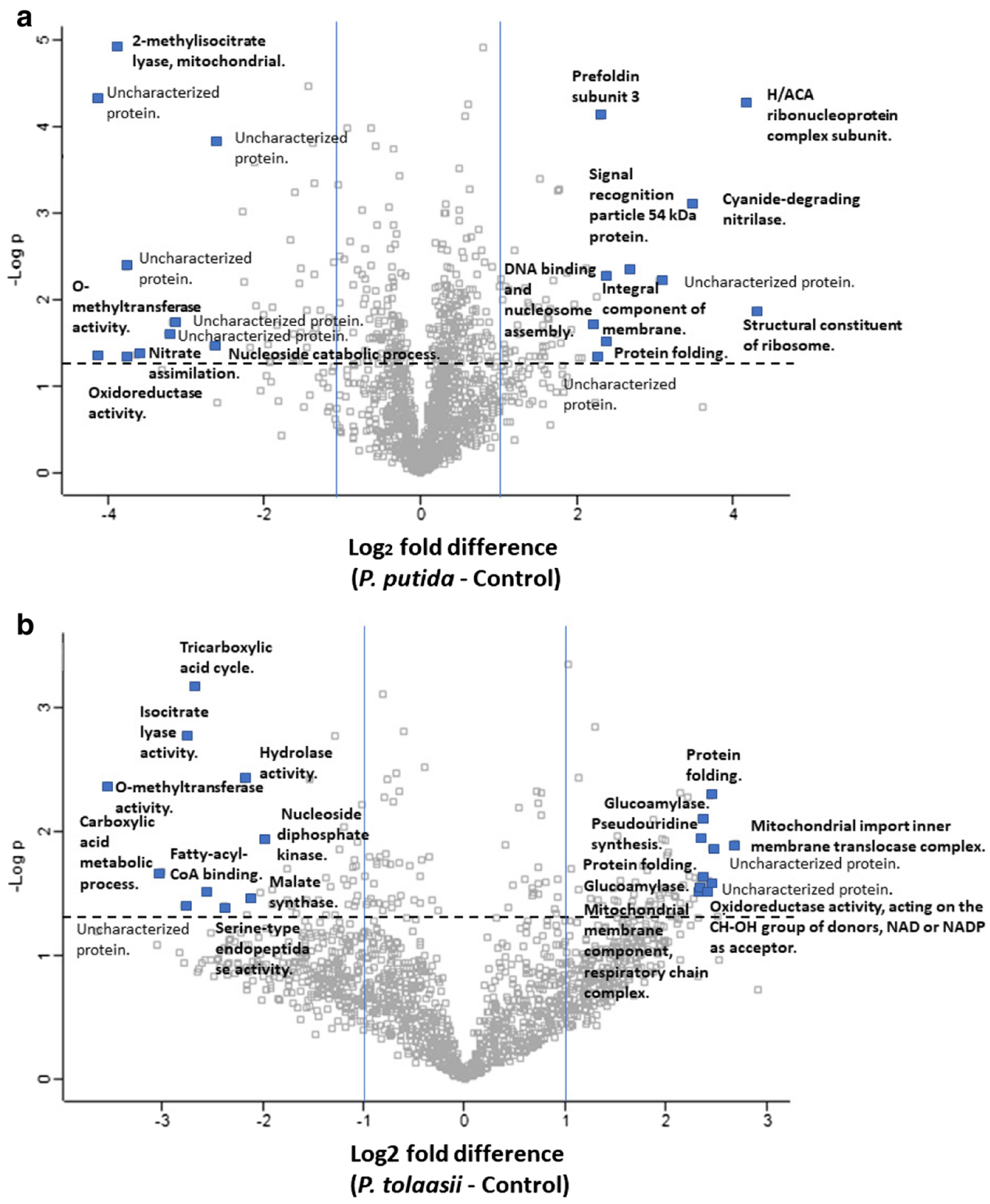

Fig. 3 Proteomic responses of T. aggressivum following $24 \mathrm{~h}$ incubation with $25 \% \mathrm{v} / \mathrm{v} 96 \mathrm{~h}$ supernatant of $P$. putida (a) or $P$. tolaasii (b). Volcano plots represent protein intensity difference $(-\log 2$ mean intensity difference) and significance in differences $(-\log P$ value) based on a two-sided t-test. Proteins above the line

\section{Discussion}

Green mould disease is characterized by white mycelium that colonises A. bisporus compost and casing and turns are considered statistically significant $(p<0.05)$ and those to the right and left of the vertical lines indicate relative fold changes $>2$. Annotations are given for the most differentially abundant proteins identified. These plots are based upon post imputed data

green due to sporulation. Brown spots on mushroom bodies are associated symptoms and in severe outbreaks no crop is produced (Seaby 1996). Many Trichoderma species, such as T. harzianum, T. atroviride, T. koningii, 
Treatment with $P$. putida/tolaasii

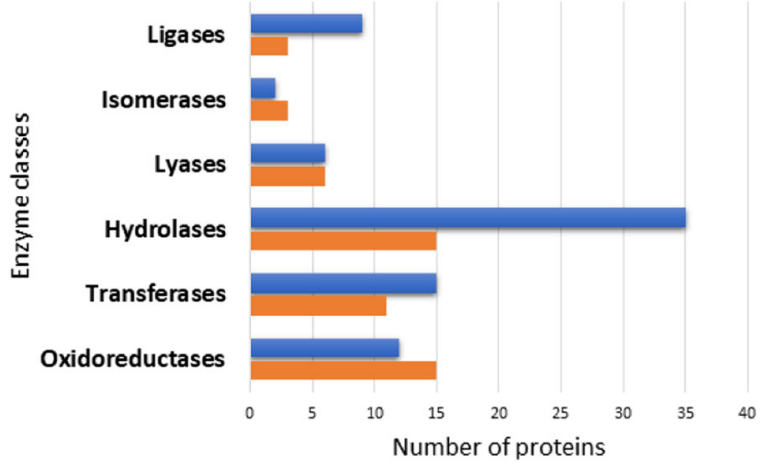

Fig. 4 Classes of enzyme identified in T. aggressivum following exposure to $P$. putida or $P$. tolaasii supernatants

T. virens can be present in mushroom growing environment but not all of these have the same capacity to induce diseases (Kosanovic et al. 2013). Before the 1990s, green mould disease was a relatively minor problem on mushroom farms (Samuels et al. 2002). However since then T. aggressivum induced green mould disease has emerged as a major problem for mushroom growers and has spread all over the world (Seaby 1996; Geels 1997; Hermosa et al. 1999; Mamoun et al. 2000; Rinker 1993; Romaine et al. 1996; Hatvani et al. 2007; Szczech et al. 2008; RomeroArenas et al. 2009; Clift and Shamshad 2009; Hatvani et al. 2012; Kosanovic et al. 2013). T. aggressivum reduces yield in mushroom facilities by being a compost competitor of A. bisporus, and not a direct pathogen of Agaricus (Krupke et al. 2003; O’Brien et al. 2017). A number of antifungal compounds (e.g. 3,4-dihydro-8-hydroxy-3methylisocoumarin) are produced by T. aggressivum and these metabolites are not produced by other, nonaggressive Trichoderma spp. (Krupke et al. 2003). Additionally, red-pepper mites, which feed on Trichoderma spores, frequently infest mushroom crops with green mould disease and so make the product unmarketable (Krupke et al. 2003).

The casing layer is an ideal environment for bacterial migration from compost, being porous and wet, thus Pseudomonas spp. are known to migrate and to exhibit chemotaxis toward A. bisporus mycelium exudates that provide growth substrates for them (Grewal and Rainey 1991). Pseudomonas genus makes up to $10 \%$ of compost for A. bisporus cultivation and sometimes more than $50 \%$ of casing bacteria (Godfrey et al. 2001). P. putida is a promoter of mushroom pinning and thus considered beneficial for mushroom production, even though the exact mechanism is unknown, it has been suggested that bacteria consume 2-ethyl-1-hexanol and 1-octen-3-ol - a self-inhibitory compounds of A. bisporus growth (Noble et al. 2009), secrete hormone-like compounds that might stimulate pinning, and produce siderophores that control pathogens (Zarenejad et al. 2012). In contrast, P. tolaasii, which is also a mushroom substrate bacterium, is known as a causal agent of brown blotch disease and so considered a major problem in mushroom production (Cho et al. 2007; Osdaghi et al. 2019). P. tolaasii can produce an antimicrobial toxin, tolaasin, under certain humidity and temperature conditions in mushroom farms. Tolaasin is a peptide containing 18 amino acids with a $\beta$ hydroxyoctanoic acid on the $\mathrm{N}$-terminus and molecular mass of $1.985 \mathrm{KDa}$ (Nutkins et al. 1991). Tolaasin causes lysis of A. bisporus mycelium (Mohammad and Sabaa 2015), disrupts cells by inducing pore formation in plasma membrane and displays biosurfactant properties (Hutchison and Johnstone 1993). Brown spots on mushrooms are caused by melanin production as a result of defence response to the toxin, tolaasiin (Saxon et al. 2014). Even though brown blotch disease does not cause any ill effects in humans, brown spotting symptoms on mushroom caps are not attractive to the consumer (Cho et al. 2007). Previous work has shown that $P$. putida, isolated from compost casing, increased mushroom yield up to $26.6 \%$ compared to the noninoculated control and P. tolaasii inhibited growth, and significantly reduced mushroom yield $(-72.5 \%)$ (Mohammad and Sabaa 2015). There is a constant search for new, effective products to be used in mushroom production. B. subtilis has been shown to promote mushroom yield and to suppress green mould disease when applied in lower concentrations than the commercial bio-fungicides based on B. velezensis (Serenade ${ }^{\circledR}$ WP (AgraQuest, Canada) (Potocnik et al. 2019). Pandin et al. (2018) demonstrated how B. velezensis QST713 gave protection to $A$. bisporus crops against green mould disease caused by T. aggressivum. Further investigations of the potential of different beneficial, A. bisporus compost and casing bacteria and their secondary metabolites are warranted. Screening for a disease control agent that promotes A. bisporus yield and suppresses the growth of mycopathogens such as T. aggressivum and others are needed. Many chemicals are no longer in use since fungicides reduce the growth of $A$. bisporus to some extent, change the casing microflora, have toxic effects and pathogens are developing resistance to them. Thus, there is an increased need for 
biorational agents that can control mushroom diseases rather than using chemicals (Grogan 2008).

In the work presented here, P. putida and P. tolaasii were cultured in nutrient broth for different periods of time, harvested and filter-sterilized to yield culture supernatants (also known as culture filtrates). Such supernatants enable a characterization of the interaction of the microbial secretome with target organisms and are a good representation of the range of toxins, enzymes and other products secreted by microbes that may play a role in pathogenesis (Mc Namara et al. 2017).

Exposure of T. aggressivum to P. tolaasii- supernatant produced growth inhibition on agar plates, significantly reduced biomass accumulation, disrupted hyphal formation and supernatants demonstrate the presence of tolaasin by HPLC. Exposure of T. aggressivum to $P$. tolaasii supernatant lead to an increase in the abundance of proteins with hydrolase, and oxidoreductase activity from Volcano plot analysis. An increase in the abundance of drug and ion binding proteins was also found. All these results indicate that in the presence of P. tolaasii supernatant there is growth inhibition and the induction of an oxidative stress response by the fungal cells.

Exposure to P. putida supernatant, in contrast, did not inhibit growth of T. aggressivum on agar plates and did not influence chitin structure and formation in mycelial wall, and hyphae elongation. Yet, it significantly stimulated T. aggressivum biomass production and -led to an increase in proteins associated with ribosome biosynthesis and protein development such as structural constituents of ribosome (20-fold), H/ACA ribonucleoprotein complex subunit (18-fold), signal recognition particle $54 \mathrm{kDa}$ protein (6.4-fold), DNA binding and nucleosome assembly protein (5.3-fold), prefoldin subunit 3 (5-fold) (Fig. 4a). These results clearly indicate that exposure of T. aggressivum to P. putida supernatant resulted in a growth stimulation response. The mechanism of this growth stimulation is as yet unknown. It may be that the bacterium degrades an inhibitor of the fungus or metabolises a substrate into a form more amenable to use by $T$. aggressivum.

The results presented here indicate that exposure to $P$. tolaasii, even though it can cause brown spotting of mushrooms, decreases T. aggressivum growth. However, exposure to P. putida, which promotes pinning of mushrooms, can stimulate the growth of T. aggressivum and thus may be an important factor in increasing the incidence and severity of green mould disease in mushroom crops and so reducing yield. Further study is planned on the possible interactive effects between P. tolaasii and P. putida both in vitro and in compost and casing where a dynamic and diverse microbiome environment is present. Different application of Pseudomonas supernatants should be further investigated regarding better yield and efficacy of disease control of A. bisporus.

Acknowledgements DK is a Postdoctoral Fellow supported by Irish Research Council. GS is the recipient of a Maynooth University Doctoral Hume scholarship. Q-Exactive mass spectrometer was funded under the SFI Research Infrastructure Call 2012; Grant Number: 12/RI/2346.

\section{Compliance with ethical standards}

Conflict of interest The authors have no conflicts of interest to declare.

Human or animals participants This article does not contain any study with human participants or animals performed by the authors.

\section{References}

Barribeau, S. M., Sadd, B. M., Du Plessis, L., \& Schmid-Hempel, P. (2014). Gene expression differences underlying genotypeby-genotype specificity in a host-parasite system. Proceedings of the National Academy of Sciences, 111, 3496-3501.

Benjamini, Y., \& Hochberg, Y. (1995). Controlling the false discovery rate: A practical and powerful approach to multiple testing. Journal of the Royal Statistical Society, Series B, 57(1), 289-300.

Chang, S.-T., \& Miles, P. G. (2004). Mushrooms. In Cultivation, nutritional value, medicinal effect, and environmental impact (2nd ed., p. 451). Boca Raton, CRC Press. https://doi. org/10.1201/9780203492086

Cho, K.-H., Kim, S.-T., \& Kim, Y.-K. (2007). Purification of a pore-forming peptide toxin, Tolaasin, produced by Pseudomonas tolaasii 6264. Journal of Biochemistry and Molecular Biology, 40(1), 113-118.

Clift, A. D., \& Shamshad, A. (2009). Modeling mites, moulds and mushroom yields in the Australian mushroom industry. In R. S. Anderssen, R. D. Braddock, \& L. T. H. Newham (Eds.), Proceedings of the 18th world IMACS/MODSIM 09 congress (pp. 491-497). Cairns: IMACS/MODSIM.

Côté, R. G., Griss, J., Dianes, J. A., Wang, R., Wright, J. C., van den Toorn, H. W. P., et al. (2012). The PRoteomics IDEntification (PRIDE) converter 2 framework: An improved suite of tools to facilitate data submission to the 
PRIDE database and the ProteomeXchange consortium. Molecular \& Cellular Proteomics, 11, 1682-1689.

Fletcher, J. T., \& Gaze, R. H. (2008). Mushroom Pest and disease control. London: Manson Publishing.

Geels, F. P. (1997). Rondetafel - bijeenkomst over Trichoderma. Champignoncultuur., 41, 13.

Godfrey, S. A. C., Harrow, S. A., Marshall, J. W., \& Klena, J. D. (2001). Characterization by $16 \mathrm{~S}$ rRNA sequence analysis of Pseudomonas causing blotch disease of cultivated Agaricus bisprus. Applied and Environmental Microbiology, 67(9), 4316- 4323.

Grewal, S. I. S., \& Rainey, P. B. (1991). Phenotypic variation of Pseudomonas putida and P. tolizasii affects the chemotactic response to Agaricus bisporus mycelial exudate. Journal of General Microbiology, 137, 2761-2768.

Grogan, H. M. (2008). Challenges facing mushroom disease control in the 21st century. In J. I. Lelley \& J. A. Buswell (Eds.), Proceeding of the sixth international conference on mushroom biology and mushroom products (pp. 120-127). Bonn, Germany: WSMBMP.

Hatvani, L., Antal, Z., Manczinger, L., Szekeres, A., Druzhinina, I. S., Kubicek, C. P., Nagy, A., Nagy, E., Vagvolgyi, C., \& Kredics, L. (2007). Green mold diseases of Agaricus and Pleurotus are caused by related but phylogenetically different Trichoderma species. Phytopathology., 97, 532-537.

Hatvani, L., Sabolic, P., Koscube, S., Kredics, L., Vagvolgyi, C., Kaliterna, J., Ivic, D., Dermic, E., \& Kosalec, I. (2012). The first report on mushroom green mould in Croatia. Archives of Industrial Hygiene and Toxicology, 63, 481-487.

Hermosa, M. R., Grondona, I., \& Monte, E. (1999). Isolation of Trichoderma harzianum Th2 from commercial mushroom compost in Spain. Plant Disease, 83, 591.

Hutchison, M. I., \& Johnstone, K. (1993). Evidence for the involvement of the surface active properties of the extracellular toxin tolaasin in the manifestation of brown blotch disease symptoms by Pseudomonas tolaasii on Agaricus bisporus. Physiological and Molecular Plant Pathology, 42, 273-384.

Kosanovic, D., Potocnik, I., Duduk, B., Vukojevic, J., Stajic, M., Rekanovic, E., \& Milijasevic-Marcic, S. (2013). Trichoderma species on Agaricus bisporus farms in Serbia and their biocontrol. The Annals of Applied Biology, 163, 218-230.

Kosanovic, D., Potocnik, I., Vukojevic, J., Stajic, M., Rekanovic, E., Stepanovic, M., \& Todorovic, B. (2015). Fungicide sensitivity of Trichoderma spp. from Agaricus bisporus farms in Serbia. Journal of Environmental Science and Health Part B Pesticides Food Contaminants and Agricultural Wastes., 50(8), 607-613.

Kredics, L., Jimenez, L.G., Naeimi, S., Czifra, D., Urban, P, Manczinger, L., Vagvolgyi, C., Hatvani L. (2010) A chalenge to mushroom growers: the green mould disease of cultivated champignons. Current Research, Technology and Education Topics in Applied Microbiology and Microbial Biotechnology. pp. 295-305.

Krupke, O. A., Castle, A. J., \& Rinker, D. L. (2003). The north American mushroom competitor, Trichoderma aggressivum f. aggressivum, produces antifungal compounds in mushroom compost that inhibit mycelial growth of the commercial mushroom Agaricus bisporus. Mycological Research, 107(12), 1467-1475.
Maher, A., Staunton, K., \& Kavanagh, K. (2018). Analysis of the effect of temperature on protein abundance in Demodexassociated Bacillus oleronius. Pathogens and Disease, 75, fty032. https://doi.org/10.1093/femspd/fty032.

Mamoun, M. L., Iapicco, R., Savoie, J.-M., \& Olivier, J. M. (2000). Green mould disease in France: Trichoderma harzianum Th2 and other species causing damage on mushroom farms. Mushroom Science., 15, 625-632.

Mc Namara, L., Carolan, J. C., Griffin, C. T., Fitzpatrick, D., \& Kavanagh, K. (2017). Analysis of the effect of entomopathogenic fungal culture filtrate on the immune response of the greater wax moth. Galleria mellonella. Journal of Insect Physiology., 100, 82-92.

Mohammad, A., \& Sabaa, A. K. (2015). In virto and in vivo impact of some Pseudomonas spp. on growth and yield of cultivated mushroom (Agaricus bisporus). Egyptian Journal of Experimental Biology (Botany)., 11(2), 163-167.

Noble, R., Dobrovin-Pennington, A., Hobbs, P. J., Pederby, J., \& Rodger, A. (2009). Volatile C8 compounds and pseudomonads influence primordium formation of Agaricus bisporus. Mycologia., 101(5), 583-591. https://doi.org/10.3852/07194.

Nutkins, J. C., Mortishire-Smith, R. J., Packman, L. C., Brodey, C. L., Rainey, P. B., Johnstone, K., \& Williams, D. H. (1991). Structure determination of tolaasin, an extracellular lipodepsipeptide produced by the mushroom pathogen Pseudomonas tolaasii Paine. Journal of the American Chemical Society, 113, 2621-2627.

O'Brien, M., Kavanagh, K., \& Grogan, H. (2017). Detection of Trichoderma aggressivum in bulk phase III substrate and the effect of T. aggressivum inoculum, supplementation and substrate-mixing on Agaricus bisporus yields. European Journal of Plant Pathology, 147(1), 199-209.

Osdaghi, E., Martins, S. J., Ramos-Sepulveda, L., Rocha Vieira, F., Pecchia, J. A., Meigs Beyer, D., Bell, T. H., Yang, Y., Hockett, K. L., \& Bull, C. T. (2019). 100 years since Tolaas: Bacterial blotch of mushrooms in the $21^{\text {st }}$ century. https://doi. org/10.1094/PDIS-03-19-0589-FE.

Pandin, C., Le Coq, D., Deschamps, J., Vedic, R., Rousseau, T., Aymerich, S., \& Briandet, R. (2018). Complete genome sequence of Bacillus velezensis QST713: A biocontrol agent that protects Agaricus bisporus crops against green mould disease. Journal of Biotechnology, 278, 10-19.

Park, J. Y., \& Agnihotri, V. P. (1969). Bacterial metabolites trigger sporophore formation in Agaricus bisporus. Nature., 222, 984.

Potocnik, I., Vukojevic, J., Stajic, M., Kosanovic, D., Rekanovic, E., Stepanovic, M., \& Milijasevic-Marcic, S. (2012). Impact of fungicides used for wheat treatment on button mushroom cultivation. Journal of Pesticides and Phytomedicine., 27(1), 9-14. https://doi.org/10.2298/PIF1201009P.

Potocnik, I., Rekanovic, E., Todorovic, B., Lukovic, J., Paunovic, D., Stanojevic, O., \& Milijasevic-Marcic, S. (2019). The effects of casing soil treatment with bacillus subtilis Ch-13 biofungicide on green mould control and mushroom yield. Journal of Pesticides and Phytomedicine., 34(1), 53-60. https://doi.org/10.2298/PIF1901053P.

Rainey, P. B. (1991). Effect of Pseudomonas putida on hyphal growth of Agricus bisporus. Mycological Research, 95, 699704. 
Rinker, D. L. (1993). Disease management strategies for Trichoderma mould. Mushroom World., 4, 3-5.

Romaine, C. P., Royse, D. J., Wuest, P. J., \& Beyer, D. M. (1996). Mushroom green mould: Cause, edaphic factors and control. Mushroom News., 44, 20-23.

Romero-Arenas, O., Lara, M. H., Huato, M. A. D., Hernandez, F. D., \& Victoria, D. A. A. (2009). The characteristics of Trichoderma harzianum as a limiting agent in edible mushrooms. Revista Colombiana de Biotecnología, 11, 143-151.

Royse, D. J., Baars, J., \& Tan, Q. (2017). Current overview of mushroom production in the world. In D. C. Zied \& A. Pardo-Giménez (Eds.), Edible and medicinal mushrooms: Technology and applications (1st ed., pp. 2-13). Wiley.https://scholar.google.com/scholar_lookup?title= Edible+and+medicinal+mushrooms:+technology +and+applications \&author=DJ+Royse \&author $=$ $\mathrm{J}+$ Baars\&author $=\mathrm{Q}+$ Tan\&publication_year $=2017 \&$

Samuels, G.J., Dodd, S.L., Gams, W., Castlebury, L.A., Petrini, O. (2002) Trichoderma species associated with the green mold epidemic of commercially grown Agaricus bisporus. Mycologia, 94, 146-170.

Saxon, E. B., Jackson, R. W., Bhumbra, S., Smith, T., \& Sockett, R. E. (2014). Bdellovibrio bacteriovorus HD100 guards against Pseudomonas tolaasii brown-blotch lesions on the surface of post-harvest Agaricus bisporus supermarket mushrooms. BMC Microbiology, 14, 163. https://doi.org/10.1186 /1471-2180-14-16.

Seaby, D. A. (1987). Infection of mushroom compost by Trichoderma species. Mushroom Journal., 179, 355-361.

Seaby, D. A. (1996). Investigation of the epidemiology of green mold of mushroom (Agaricus bisporus) compost caused by Trichoderma harzianum. Plant Pathology, 45, 913-923.

Sinden, J., \& Hauser, E. (1953). Nature and control of three mildew diseases of mushrooms in America. Mushroom Science., 2, 177-180.

Soler-Rivas, C., Jolivet, S., Arpin, N., Olivier, J. M., \& Wichers, H. J. (1999). Biochemical and physiological aspects of brown blotch disease of Agaricus bisporus. FEMS Microbiology Reviews, 23(5), 591-614.
Soler-Rivas, C., Arpin, N., Olivier, J. M., \& Wichers, H. J. (2000). Discoloration and tyrosinase activity in Agaricus bisporus fruit bodies infected with various pathogens. Mycological Research, 104(3), 351-356.

Szczech, M., Staniaszek, M., Habdas, H., Ulinski, Z., \& Szymanski, J. (2008). Trichoderma spp. - The cause of green mould on polish mushroom farms. Vegetable Crops Research Bulletin., 69, 105-114.

Tolaas, A. G. (1915). A bacterial disease of cultivated mushrooms. Phytopathology., 5, 51-54.

Watson, A. K., Williams, T. A., Williams, B. A., Moore, K. A., Hirt, R. P., \& Embley, T. M. (2015). Transcriptomic profiling of host-parasite interactions in the microsporidian Trachipleistophora hominis. BMC Genomics, 16, 975-983.

Wells, J. M., Sapers, G. M., Fett, W. F., Butterfield, J. E., Jones, J. B., Bouzar, H., \& Miller, F. C. (1996). Postharvest discoloration of the cultivated mushroom Agaricus bisporus caused by Pseudomonas tolaasii, $P$. 'reactans', and $P$. 'gingeri'. Phytopathology, 86, 1098-1104.

Wong, W. C., Fletcher, J. T., Unsworth, B. A., \& Preece, T. F. (1982). A note on ginger blotch, a new bacterial disease of the cultivated mushroom. Agaricus bisporus. Journal of Applied Bacteriology., 52, 43-48.

Yates, J. R., Ruse, C. I., \& Nakorchevsky, A. (2009). Proteomics by mass spectrometry: Approaches, advances, and applications. Annual Review of Biomedical Engineering, 11, 49-79.

Young, J. M. (1970). Drippy gill: A bacterial disease of cultivated mushrooms caused by Pseudomonas agarici n.sp. New Zealand Journal of Agricultural Research, 13(4), 977-990.

Zarenejad, F., Yakhchali, B., \& Rasooli, I. (2012). Evaluation of indigenous potent mushroom growth promoting bacteria (MGPB) on Agaricus bisporus production. World Journal of Microbiology and Biotechnology, 28(1), 99-104.

Zhang, Y., Fonslow, B. R., Shan, B., Baek, M.-C., \& Yates III, J. R. (2013). Protein analysis by shotgun/bottom-up proteomics. Chemical Reviews, 113, 2343-2394.

Zhu, J.-Y., Yang, P., Zhang, Z., Wu, G.-X., \& Yang, B. (2013). Transcriptomic immune response of Tenebrio molitor pupae to parasitization by Scleroderma guani. PLoS One, 8, e54411. 